\title{
The clinical and epidemiologic consequences of redefining treatment criteria: Who should be treated?
}

\author{
Michael McClung, MD(1)
}

\section{McClung M. \\ The clinical and epidemiologic consequences of redefining treatment criteria: Who should be treated? Salud Publica Mex 2009;5 I suppl I:S46-S5 I.}

\begin{abstract}
Bone mineral density (BMD) is the tool for diagnosing osteoporosis in older adults. However, BMD alone is not sufficient for deciding who should be given treatment at either the individual patient or the public health level. Robust, scientifically validated algorithms that combine BMD with other clinical risk factors provide more accurate assessment of fracture probability. New guidelines for managing osteoporosis are now based on the assessment of absolute fracture risk, not simply on bone mineral density values. Accordingly, treatment resources will be redirected away from young postmenopausal women with low BMD and low fracture risk toward older adults at moderate or high risk for fracture. It is expected that, with these algorithms, the cost and effectiveness of medical care for patients with osteoporosis will be improved.
\end{abstract}

Key words: bone density, fracture risk, osteoporosis treatment

\section{McClung M.}

Consecuencias clínicas y epidemiológicas de la redefinición de criterios de tratamiento: ¿quién debe tratarse?

Salud Publica Mex 2009;5 I supl I:S46-S5I.

\section{Resumen}

La densidad mineral ósea (DMO) es la herramienta de diagnóstico para osteoporosis en adultos mayores. Sin embargo, por sí sola la DMO no es suficiente para decidir quién debe recibir tratamiento ni al nivel del paciente individual ni al nivel de salud pública. Los algoritmos robustos, científicamente comprobados, que combinan DMO con otros factores de riesgo clínicos proporcionan una evaluación más precisa de la probabilidad de fractura. Los nuevos lineamientos para el manejo de la osteoporosis se basan en la evaluación del riesgo de fractura absoluto, no ya tan sólo en los valores de densidad mineral ósea. Por lo tanto, los recursos para el tratamiento cambiarán, de dirigirse a mujeres postmenopáusicas jóvenes con baja DMO y bajo riesgo de fractura, a mujeres mayores con riesgo de fractura alto o moderado. Se espera que con estos algoritmos haya una mejora en cuanto al costo y la efectividad de la atención médica para pacientes con osteoporosis.

Palabras clave: densidad ósea; riesgo de fractura; tratamiento de la osteoporosis

Since the submission of this manuscript, the World Health Organization absolute fracture risk algorithm (FRAXTM) has become available (http://www.shef. ac.uk/FRAX/) and has been incorporated into the revised clinical guidelines of United States National Osteoporosis Foundation (http://nof.org/professionals/ Clinicians_Guide.htm).

(I) Oregon Osteoporosis Center, Portland, Oregon, USA

Received on: January 7, 2008 • Accepted on: March 7, 2008

Address reprint requests to: Michael McClung, Director. Oregon Osteoporosis Center. 5050 NE Hoyt Street, Suite 65I. Portland, OR 972 I 3 USA.

E-mail:mmcclung@orost.com 
$\mathrm{T}_{\mathrm{p}}^{\mathrm{h}}$ he availability of pharmacological therapies that prevent bone loss and reduce fracture risk poses the important questions of which patients should receive these therapies and how can we best identify those patients. These issues have relevance for both clinicians and planners of health policy. The purpose of managing patients with or at risk for osteoporosis is to reduce the likelihood of fracture, the only important clinical consequence of this disorder. ${ }^{1}$ Lifestyle changes such as nutrition, exercise and avoidance of smoking have multiple salutary effects including the possible slowing of bone loss. Providing adequate intakes of calcium and vitamin $\mathrm{D}$ decrease the frequency of falls and fractures in older adults and may have other extra-skeletal benefits. ${ }^{2}$ Thus, pursuing a health-promoting lifestyle is appropriate for all adults. This discussion will focus on which adults should receive pharmacological therapy and strategies to identify those patients.

\section{Clinical effectiveness of reducing fracture risk}

In prospective clinical trials, several drugs in various classes have significantly decreased vertebral fracture risk in postmenopausal women with osteoporosis. . $^{3-16}$ Alendronate, risedronate, zoledronic acid, teriparatide and strontium ranelate have reduced the incidence of non-vertebral fractures. 6,8,11,12,15,16 Three bisphosphonates (alendronate, risedronate and zoledronic acid) have reduced the risk of hip fracture. ${ }^{4,11,16}$ All of the clinical trials leading to registration of agents to treat osteoporosis evaluated efficacy in older postmenopausal women known to have osteoporosis, defined as either bone mineral density (BMD) values consistent with the World Health Organization (WHO) criteria or having a previous vertebral fracture and whose risk of vertebral fractures ranged from about $1 \%$ to about $10 \%$ per year.

These results provide strong evidence for the use of pharmacological therapy in postmenopausal women (and probably older men) with osteoporosis. However, most fragility fractures occur in patients who do not have BMD values consistent with osteoporosis. ${ }^{17,18}$ Unfortunately, we lack evidence that drug treatment reduces fracture risk in patients who do not have osteoporosis. With the exception of estrogen, no drug has been shown to reduce fracture risk in patients without osteoporosis. Two studies with bisphosphonates included subjects with osteoporosis as well as those who did not have osteoporosis or whose osteoporosis status was not known. ${ }^{5,11}$ Clinical and hip fracture risk reduction was confined to those women whose bone density values meet the criteria for osteoporosis. Post hoc analyses of studies with raloxifene and alendronate have reported fracture risk reduction in women with "osteopenia" ${ }^{19,20}$ In neither study, however, was treatment effect evaluated in patients whose BMD values at both the hip and spine were not consistent with osteoporosis and who did not have previous vertebral fractures.

Studies of non-estrogen treatments to prevent osteoporosis have evaluated BMD changes as the primary endpoint and have been too small to assess the effects of therapy on fracture rates. ${ }^{21-26}$ In the Women's Health Initiative (WHI) studies, estrogen-progestin and estrogen alone reduced the risk of clinical fractures, including a 34\% reduction in fractures of the spine and hip, in women not selected on the basis of fracture risk. ${ }^{27,28}$ The averages ages of women in the two studies were 62 and 61 years, respectively. The annualized incidence of vertebral fractures was $0.15 \%$ in the estrogen plus progestin arm of the study and $0.17 \%$ in the estrogen only arm. Absolute fracture risk reduction was 0.05-0.06\% per year in these low risk populations. Between 1600 and 2000 women would need to be treated for a year to prevent one hip or spine fracture.

This clinical evidence documents that treating patients known to have osteoporosis effectively prevents fractures. The studies do not provide clear direction of how to reduce fracture risk in patients at lower risk.

\section{Economic considerations}

Economic considerations are important to justify the allocation of healthcare resources and to identify patients to receive drugs used for the treatment and prevention of chronic medical problems such as osteoporosis. Current models for estimating cost-effectiveness of bone-specific treatments include important risk factors such as age, low BMD and prior fracture history; the disutility associated with non-hip fracture; and the consequences for society as well as the individual patient. ${ }^{29}$ Cost-effectiveness has been demonstrated for several of our treatments in women with osteoporosis. ${ }^{30-32}$ Data from Western Europe and North America are generally used, and common cost-effective thresholds of between \$40 000-50 000 per quality-adjusted life-year (QALY). An analysis with alendronate in postmenopausal women with low BMD demonstrated that the cost per QALY decreased substantially with advanced age and the presence of a prior vertebral fracture, both of which are strong and well recognized risk factors for both hip and spine fracture. ${ }^{30}$ Cost-effectiveness was demonstrated in women between ages 65 and 77 with a prior vertebral fracture. Using similar criteria, risedronate therapy was cost-effective in women 65 and older with either previous vertebral fractures or T-scores of 
-2.5 or lower. ${ }^{31}$ These results were consistent with the cost-effective analysis performed by a task force of the National Osteoporosis Foundation, demonstrating that alendronate therapy would be cost-effective in a 65 year-old woman without a prior fracture only if BMD values were between -2.5 and -3 or lower. ${ }^{33}$ In contrast, an analysis by Schoesboe and colleagues demonstrated that the cost per QALY with alendronate therapy in women ages 55-74 with femoral neck T-score values between -1.5 and -2.4 without other risk factors ranged between $\$ 70000$ and $\$ 332000$, substantially above the generally accepted threshold. ${ }^{34}$ Only the presence of very strong BMD-independent risk factors such as previous vertebral fracture or glucocorticoid use would render therapy cost-effective in these women without BMD criteria for osteoporosis.

These economic analyses suggest that therapy with our current treatment options is not cost-effective in most patients who do not have osteoporosis, even if we were confident that therapy reduced fracture risk in those lower risk patients. The absolute fracture risk in the patients selected for therapy is more important in determining cost-effectiveness than is the relative risk reduction of the therapy. ${ }^{35}$ The agreement of the clinical and economic data in which both fracture protection and cost-effectiveness of approved agents have been demonstrated only in moderate or high risk patients provides a strong basis for recommendations that therapy be specifically targeted to those patients.

\section{Thresholds for diagnosis and treatment}

Osteoporosis is now defined as a disorder of increased fracture risk due to skeletal fragility. ${ }^{36}$ Impaired bone strength is the result of the combined effects of low bone mineral density and changes in bone architecture and quality. Because measurements of bone architecture, quality and strength are not available in the clinical setting, measurement of BMD is the clinical tool for the assessment of osteoporosis. The diagnosis of osteoporosis in postmenopausal women is currently defined by the $\mathrm{WHO}$ as a BMD value that is 2.5 standard deviations below the average value in healthy young women (T-score of -2.5). ${ }^{37}$

The importance of BMD as an index of fracture risk in older women is well established. For each SD decrease in age-adjusted BMD, the relative risk of fracture increases by 1.5-2.5 fold. ${ }^{38}$ However, other clinical risk factors exist that are at least partially independent of BMD. The relationship between BMD and fracture risk is strongly modified by age. ${ }^{39} \mathrm{At}$ any given level of $\mathrm{BMD}$, younger women are at lower risk of fracture than are older women. Pre-existing fracture substantially increases the subsequent fracture. ${ }^{40} \mathrm{~A}$ history of any prior fragility fracture increases the relative risk for having a subsequent osteoporotic fracture by a factor of 1.74 (confidence interval 1.57-1.92) in women after adjustment for BMD. Other factors including family history, indices of bone turnover and co-existing medical problems significantly affect fracture probability independently of BMD. ${ }^{41}$ The BMD threshold for the diagnosis of osteoporosis does not adequately serve as an appropriate threshold at which drug therapy would be appropriate. While the BMD T-score is used to diagnose osteoporosis in postmenopausal women, the T-score value provides little information about absolute fracture risk until it is combined with the rest of the clinical information.

\section{Clinical guidelines for treating osteoporosis}

Recent clinical guidelines have recognized the inadequacy of BMD alone as the determinant of an intervention threshold by proposing different BMD values for considering therapy depending upon the presence or absence of other important risk factors. Therapy is generally recommended for all postmenopausal women with T-score values below an arbitrary value and in those with less low BMD if risk factors are present. In Mexico, the AMMOM task force proposed treatment of all postmenopausal women with osteoporosis; women over age 65 with osteopenia and at least one additional risk factor; and women between ages 50 and 65 with osteopenia, one additional risk factor and increased levels of biochemical markers of bone remodeling. ${ }^{42}$ Preliminary guidelines from the National Institute for Health and Clinical Excellence (NICE) in the UK have combined age, fracture history, BMD and other risk factors. ${ }^{43}$ Therapy is recommended in women aged 75 years or older with a prior fracture without the need for dual X-ray absorptiometry (DXA) scanning, in those aged 65-74 years if a T-score of -2.5 or below is confirmed by DXA scanning, and for women below age 65 if they have a BMD T-score of -3 or lower. Bisphosphonate therapy is also recommended for the primary prevention of osteoporotic fragility fractures in women aged 75 years or older with a T-score of -2.5 or below who have one or more of several clinical risk factors.

In the United States, the National Osteoporosis Foundation (NOF) made detailed recommendations for osteoporosis management based initially on a statistical model for determining cost-utility of treatment. ${ }^{34}$ Specific recommendations were made for various combinations of clinical risk factors including BMD. A condensed, simplified version recommended treatment of all postmenopausal women with T-score values of -2 or lower, 
and for those with values between -1.5 and - 2 if risk factors were present. ${ }^{44}$ Other North American guidelines are generally more conservative than those of the NOF. ${ }^{45-47}$ Most recommend using a combination of BMD and risk factors to select patients for treatment. Variability exists among the guidelines in the T-scores at which therapy is recommended and in the risk factors upon which the BMD threshold for therapy is modified.

\section{Models based on absolute fracture risk}

There is now strong consensus that decision about beginning osteoporosis therapy should be based on the patient's absolute risk of fracture. ${ }^{48}$ Several models for estimating fracture risk by combining information about BMD with clinical risk factors including falls and frailty have been devised and evaluated. ${ }^{49-52}$ With the objective of developing a tool with which to determine treatment thresholds, an algorithm to assess fracture probability in individual patients is being developed by a task force of the World Health Organization. ${ }^{53}$ By combining data from almost all of the large observational studies performed in populations in different parts of the world, the strength of the correlations between risk factors and fracture risk were accurately quantified. Risk factors included in the algorithm are easily acquired, independent of BMD and amenable to pharmacological intervention. These include BMD of the femoral neck, age, personal and family history of fracture, current smoking, excessive alcohol intake, history of glucocorticoid therapy and secondary osteoporosis (rheumatoid arthritis). BMI will be used as an alternative to BMD when the latter is not available. The complex interplay among the risk factors has been taken into account, providing a robust and validated tool. ${ }^{54}$ The model estimates the absolute risk (probability) of experiencing a clinical fragility fracture of the hip, spine, humerus or forearm over the next 10 years. Decisions about specific levels of risk at which treatment is recommended will be left to individual countries and health systems based upon the availability of healthcare resources and the position of osteoporosis among the various medical priorities. ${ }^{55}$

\section{Implications and limitations}

The move from BMD-based treatment thresholds to a risk-based strategy will recommend therapy costeffectively and will target toward patients who will receive the greatest clinical benefit. A shift will occur from treatment being recommended from younger postmenopausal women with modestly low BMD but whose risk for fracture is low to older patients without osteoporosis but whose risk is moderate to high due to other risk factors. ${ }^{56}$ The question of whether to treat patients with "osteopenia" will no longer be pertinent. Rather, absolute risk assessment will be used to identify specific patients who do not have osteoporosis who would benefit from drug therapy. The specific implications for Mexico of which and how many patients will be treated will depend upon appropriate analysis and estimates of cost utility within the Mexican health system. The availability of epidemiological data about fracture incidence in Mexico will add to the value of the fracture risk assessment tool for Mexican clinicians and health policy planners. $.7,58$

In parts of Mexico where access to bone density testing is limited, the fracture risk algorithm without BMD could be used to make treatment decisions (figure 1). Where bone density testing is available, risk assessment could also be used to select patients for whom testing would be appropriate. Testing would be most valuable in patients with intermediate risk near the threshold for treatment. BMD testing would not be indicated if risk based on clinical factors is low. As in circumstances where BMD is not available, therapy could be considered without BMD testing for patients at high risk based on clinical risk factors.

A major limitation of using a risk-based treatment threshold is that little information exists about the ef-

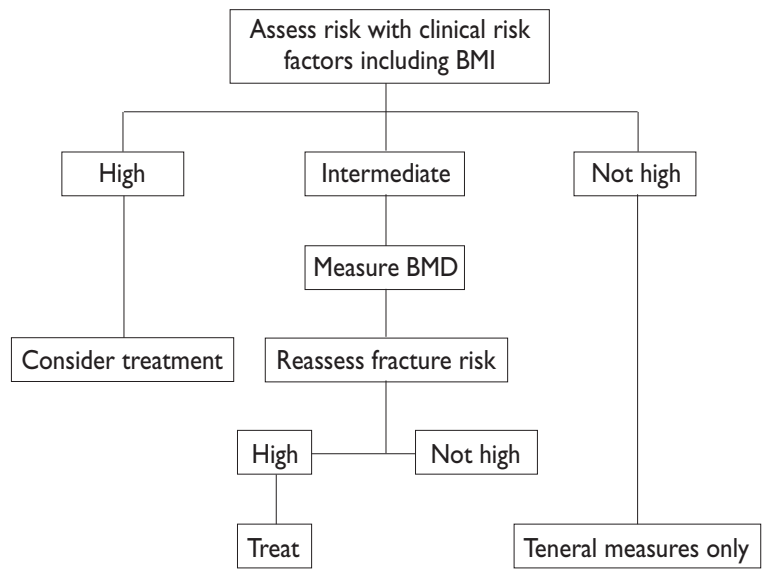

Figure I. RISK ASSESSMENT IN MANAGEMENT OF POSTMENOPAUSAL OSTEOPOROSIS.THIS MODEL PROPOSES ASSIGNING PATIENTS INTO THREE RISK GROUPS BASED ON CLINICAL RISK FACTORS. BMD TESTING WOULD BE APPROPRIATE FOR THE INTERMEDIATE RISK GROUP. RISK WOULD THEN BE RE-ASSESSED TO DECIDE ABOUt tREATMENT. When BMD testing IS NOT AVAILABLE, THE INTERMEDIATE CATEGORY WOULD NOT EXIST, aNd patients WOUld be assigned to the High and Not HIGH GROUPS BASED ON CLINICAL RISK FACTORS ALONE 
fectiveness of drug treatment in patients selected on the basis of fracture risk, a problem shared by most of the current BMD-based treatment guidelines. The risk-based approach will be applicable only in older adults. It will not apply to many other patients in which treatment decisions must be made including women in early menopause, those receiving drugs causing bone loss such as aromatase inhibitors, and the management of low bone mass in young adults.

\section{Conclusions}

The availability of data from epidemiological studies and clinical trials provides strong evidence upon which to base recommendations about which patients are candidates for pharmacological therapy to prevent fractures related to osteoporosis. Distinctions must be made between criteria used for diagnosing osteoporosis (BMD testing) and for determining who to treat. Moving from BMD-based to risk-based treatment indications will have valuable implications for health systems, for clinicians and for patients. Treatment will be directed at individuals who stand to benefit the most, and health systems will be able to estimate both the cost and the impact of treatment strategies.

\section{References}

I. Delmas PD. Treatment of postmenopausal osteoporosis. Lancet 2002;359:2018-2026.

2. Holick MF.Vitamin D deficiency. N Engl J Med 2007;357:266-28I. 3. Liberman UA, Weiss SR, Broll J, Minne HW, Quan H, Bell NH, et al. Effect of oral alendronate on bone mineral density and the incidence of fractures in postmenopausal osteoporosis. The Alendronate Phase III Osteoporosis Treatment Study Group. N Engl J Med 1995;333: I437-I 443. 4. Black DM, Cummings SR, Karpf DB, Cauley JA, Thompson DE, Nevitt $M C$, et al. Randomised trial of effect of alendronate on risk of fracture in women with existing vertebral fractures. Fracture Intervention Trial Research Group. Lancet 1996;348:1535-154I.

5. Cummings SR, Black DM,Thompson DE,Applegate WB, Barrett-Connor $E$, Musliner TA, et al. Effect of alendronate on risk of fracture in women with low bone density but without vertebral fractures: results from the Fracture Intervention Trial. JAMA 1998;280:2077-2082.

6. Pols HA, Felsenberg D, Hanley DA, Stepan J, Munoz-Torres M,Wilkin TJ, et al. Multinational, placebo-controlled, randomized trial of the effects of alendronate on bone density and fracture risk in postmenopausal women with low bone mass: results of the FOSIT study. Osteoporos Int 1999; 9:461-468.

7. Ettinger B, Black DM, Mitlak BH, Knickerbocker RK, Nickelsen T, Genant HK, et al. Reduction of vertebral fracture risk in postmenopausal women with osteoporosis treated with raloxifene: results from a 3-year randomized clinical trial. JAMA 1999;282:637-645.

8. Harris ST,Watts NB, Genant HK, McKeever CD, Hangartner T, Keller $M$, et al. Effects of risedronate treatment on vertebral and nonvertebral fractures in women with postmenopausal osteoporosis: a randomized controlled trial.JAMA 1999;282:1344-1352.
9. Chesnut III CH, Silverman S, Andriano K, Genant H, Gimona A, Harris $S$, et al.A randomized trial of nasal spray salmon calcitonin in postmenopausal women with established osteoporosis: the prevent recurrence of osteoporotic fractures study.Am J Med 2000;109:267-276. I0. Reginster J, Minne HW, Sorensen OH, Hooper M, Roux C, Brandi ML, et al. Randomized trial of the effects of risedronate on vertebral fractures in women with established postmenopausal osteoporosis. Osteoporos Int 2000; 11:83-91.

II. McClung MR, Geusens P, Miller P, Zippel H, Bensen WG, Roux C, et al. Effect of risedronate on the risk of hip fracture in elderly women. $N$ Engl J Med 200I;344:333-340.

12. Neer RM, Arnaud CD, Zanchetta JR, Prince R, Gaich GA, Reginster JY, et al. Effect of parathyroid hormone (I-34) on fractures and bone mineral density in postmenopausal women with osteoporosis. N Engl J Med 2001;344: 1434-| 144I.

13. Chesnut III CH, Skag A, Christiansen C, Recker R, Stakkestad JA, Hoiseth $A$, et al. Effects of oral ibandronate administered daily or intermittently on fracture risk in postmenopausal osteoporosis.J Bone Miner Res 2004; 19:124I-1249.

I4. Meunier PJ, Roux C, Seeman E, Ortolani S, Badurski JE, Spector TD, et al. The effects of strontium ranelate on the risk of vertebral fracture in women with postmenopausal osteoporosis. N Engl J Med 2004;350: 459-468.

15. Reginster JY, Seeman E, De Vernejoul MC,Adami S, Compston J, Phenekos C, et al. Strontium ranelate reduces the risk of nonvertebral fractures in postmenopausal women with osteoporosis.J Clin Endocrinol Metab 2005;90:2816-2822.

16. Black DM, Delmas PD, Eastell R, Reid IR, Boonen S, Cauley JA, et al. Once-yearly zoledronic acid for treatment of postmenopausal osteoporosis. N Engl J Med 2007;356: 1809-I822.

17. Wainwright SA, Marshall LM, Ensrud KE, Cauley JA, Black DM, Hillier TA, et al. Hip fracture in women without osteoporosis. J Clin Endocrinol Metab 2005;90:2787-2793.

18. Pasco JA, Seeman E, Henry MJ, Merriman EN, Nicholson GC, Kotowicz MA. The population burden of fractures originates in women with osteopenia, not osteoporosis. Osteoporos Int 2006; 17: 1404-1409. 19. Kanis JA, Johnell O, Black DM, Downs Jr RW, Sarkar S, Fuerst $T$, et al. Effect of raloxifene on the risk of new vertebral fracture in postmenopausal women with osteopenia or osteoporosis: a reanalysis of the Multiple Outcomes of Raloxifene Evaluation trial. Bone 2003;33: 293-300.

20. Quandt SA, Thompson DE, Schneider DL, Nevitt MC, Black DM. Effect of alendronate on vertebral fracture risk in women with bone mineral density T scores of -1.6 to -2.5 at the femoral neck. Mayo Clin Proc 2005;80:343-349.

21. Delmas PD, Bjarnason NH, Mitlak BH, Ravoux AC, Shah AS, Huster WJ, et al. Effects of raloxifene on bone mineral density, serum cholesterol concentrations, and uterine endometrium in postmenopausal women. N Engl J Med 1997;337: 1641-I647.

22. McClung M, Clemmesen B, Daifotis A, Gilchrist N, Eisman J,Weinstein RS, et al. The use of alendronate for prevention of postmenopausal osteoporosis. Ann Intern Med 1998;128:253-26I.

23. Hosking D, Chilvers C, Christiansen C, Ravn P,Wasnich R, Ross P, et al. Prevention of early postmenopausal bone loss with oral alendronate. $\mathrm{N}$ Engl J Med 1998;338:485-492.

24. Mortensen L. Charles P, Bekker PJ, Digennaro J, Johnston Jr CC. Risedronate increases bone mass in an early postmenopausal population: two years of treatment plus one year of follow-up. J Clin Endocrinol Metab 1998;83:396-402.

25. Fogelman I, Ribot C, Smith R, Ethgen D, Sod E, Reginster JY. Risedronate reverses bone loss in postmenopausal women with low bone mass: results from a multinational, double-blind, placebo-controlled trial. BMD-MN Study Group.J Clin Endocrinol Metab 2000;85:1895-1900. 
26. McClung MR, Wasnich RD, Recker R, Cauley JA, Chesnut III CH, Ensrud KE, et al. Oral daily ibandronate prevents bone loss in early postmenopausal women without osteoporosis. J Bone Miner Res 2004;19:11-18

27. Rossouw JE, Anderson GL, Prentice RL, LaCroix AZ, Kooperberg C, Stefanick ML, et al. Risks and benefits of estrogen plus progestin in healthy postmenopausal women: principal results from the Women's Health Initiative randomized controlled trial.JAMA 2002;288:32I-333. 28. Anderson GL, Limacher M,Assaf AR, Bassford T, Beresford TA, Black $\mathrm{H}$, et al. Effects of conjugated equine estrogen in postmenopausal women with hysterectomy: the Women's Health Initiative randomized controlled trial.JAMA 2004;29I:I70I-I7I2.

29. Zethraeus N, Ben Sedrine W, Caulin F, Corcaud S, Gathon HJ, Haim $\mathrm{M}$, et al. Models for assessing the cost-effectiveness of the treatment and prevention of osteoporosis. Osteoporos Int 2002;13:84I-857.

30. Johnell O, Jonsson B, Jonsson L, Black D. Cost-effectiveness of alendronate (Fosamax) for the treatment of osteoporosis and prevention of fractures. Pharmacoeconomics 2003;21:305-314.

31. Kanis JA, Borgstrom F, Johnell O, Jonsson B. Cost-effectiveness of risedronate for the treatment of osteoporosis and prevention of fractures in postmenopausal women. Osteoporos Int 2004;15:862-871.

32. Lundkvist J, Johnell O, Cooper C, Sykes D. Economic evaluation of parathyroid hormone (PTH) in the treatment of osteoporosis in postmenopausal women. Osteoporos Int 2006; 17:201-21I.

33. National Osteoporosis Foundation. Analysis of the effectiveness and cost of screening and treatment strategies for osteoporosis: a basis for development of practice guidelines. Osteoporosis Int 1998;8(Suppl 4): SI-S88.

34. Schousboe JT, Nyman JA, Kane RL, Ensrud KE. Cost-effectiveness of alendronate therapy for osteopenic postmenopausal women. Ann Intern Med 2005; | 142:734-74I.

35. Seeman E, Eisman JQ. Treatment of osteoporosis: why, whom, when and how to treat. The single most important consideration is the individual's absolute risk of fracture. Med J Aust 2004;180:298-303. 36. NIH Consensus Development Panel on Osteoporosis: Prevention, Diagnosis and Therapy Osteoporosis diagnosis and therapy. JAMA 200।;285:785-795.

37. Kanis JA. Diagnosis of osteoporosis and assessment of fracture risk. Lancet 2002;359:1929-1936.

38. Johnell O, Kanis JA, Oden A, Johansson H, De Laet C, Delmas P, et al. Predictive value of $B M D$ for hip and other fractures.J Bone Miner Res 2005;20: II85-1194

39. Kanis JA, Johnell O, Oden A, Dawson A, De Laet C, Jonsson B. Ten year probabilities of osteoporotic fractures according to $B M D$ and diagnostic thresholds. Osteoporos Int 200I; 12:989-995.

40. Kanis JA, Johnell O, De Laet C, Johansson H, Oden A, Delmas P, et al. A meta-analysis of previous fracture and subsequent fracture risk. Bone 2004:35:375-382.

4I. De Laet C, Oden A, Johansson H, Johnell O, Jonsson B, Kanis JA. The impact of the use of multiple risk indicators for fracture on case-finding strategies: a mathematical approach. Osteoporos Int 2005; 16:313-318. 42. Asociacion Mexicana de Metabolismo Oseo y Mineral (AMMOM). Consenso Mexicano de Osteoporosis. 2000 http://www.osteoporosiscenter.com/OSTCENTER.COM/c0I4-I.htm.
43. National Institute for Health and Clinical Excellence (NICE) Appraisal Consultation Document: Alendronate, etidronate, risedronate, raloxifene and strontium ranelate for the primary prevention of osteoporotic fragility fractures in postmenopausal women. 2005 http://www.nice.org. uk/docref.aspx?o=369163.

44. National Osteoporosis Foundation. Physician's guide to prevention and treatment of osteoporosis. Washington DC 2003.

45. American Association of Clinical Endocrinologists. Medical guidelines for clinical practice for the prevention and treatment of postmenopausal osteoporosis: 2001 edition, with selected updates for 2003. Endocr Pract 2003;9:544-564.

46. Cheung AM, Feig DS, Kapral M, Diaz-Granados N, Dodin S. Prevention of osteoporosis and osteoporotic fractures in postmenopausal women: recommendation statement from the Canadian Task Force on Preventive Health Care. CMAJ 2004;170:1665-1667.

47. Ettinger B, Harris S, Kendler D, Kessel B, McClung MR, and The Board of Trustees of the North American Menopause Society (NAMS). Management of osteoporosis in postmenopausal women. Menopause 2006; 13:340-367.

48. Kanis JA, Johnell O, Oden A, De Laet C, Oglesby A, Jonsson B. Intervention thresholds for osteoporosis. Bone 2002;31:26-31. 49. Black DM, Steinbuch M, Palermo L, Dargent-Molina P, Lindsay R, Hoseyni MS, et al. An assessment tool for predicting fracture risk in postmenopausal women. Osteoporos Int 2001;12:519-528.

50. Ettinger B, Hillier TA, Pressman A, Che M, Hanley DA. Simple computer model for calculating and reporting 5-year osteoporotic fracture risk in postmenopausal women. JWomens Health (Larchmt) 2005; 14:159-17I. 5I. Henry MJ, Pasco JA, Sanders KM, Nicholson GC, Kotowicz MA. Fracture Risk (FRISK) Score: Geelong Osteoporosis Study. Radiology 2006;241:190-196.

52. Van Staa TP, Geusens P, Kanis JA, Leufkens HG, Gehlbach S, Cooper C.A simple clinical score for estimating the long-term risk of fracture in post-menopausal women. QJM 2006;99:673-682.

53. Kanis JA, Borgstrom F, De Laet C, Johansson H, Johnell O, Jonsson B, et al. Assessment of fracture risk. Osteoporos Int 2005; 16:58|-589. 54. Kanis JA, Oden A, Johnell O, Johansson H, De Laet C, Brown J, et al. The use of clinical risk factors enhances the performance of BMD in the prediction of hip and osteoporotic fractures in men and women. Osteoporos Int 2007; 18: 1033-1046.

55. Borgstrom F, Johnell O, Kanis JA, Jonsson B, Rehnberg C. At what hip fracture risk is it cost-effective to treat?: International intervention thresholds for the treatment of osteoporosis. Osteoporos Int 2006; I0: 1459-|47|.

56. McClung MR. Do current management strategies and guidelines adequately address fracture risk? Bone 2006;38(Suppl 2):SI3-SI7. 57. Morales-Torres J, Gutiérrez-Ureña $S$ and Osteoporosis Committee of Pan-American League of Associations for Rheumatology (PANLAR). The burden of osteoporosis in Latin America. Osteoporos Int 2004; I5:625-632. 58. Clark P, Lavielle P, Franco-Marina F, Ramírez E, Salmerón J, Kanis JA, et al. Incidence rates and life-time risk of hip fractures in Mexicans over 50 years of age: a population-based study. Osteoporos Int 2005; 16:20252030. 